\title{
Teachers as Transformative Intellectuals: Democracy in the Classroom
}

\author{
Ahmed A. Osman \\ Garissa University College \\ (A Constituent College of Moi University) \\ School of Education. Department of Curriculum, Instruction \& Educational Media
}

\begin{abstract}
Democracy in education is the rights of the teachers to teach truthfully and employ their reason to the full extent of their intellectual powers. It is the freedom of professionally qualified persons to inquire, discover, publish and teach as they see it in their field of competence, without any control or authority of rational methods by which truth is established. Democracy is essential to the fulfillment of the purpose of the school. Teachers should be protected from censorship or restraint that unreasonably interferes with their obligation to expose students to controversial issues and to help students express their own views on such issues. The teacher's responsibility should be to show objectivity to see that various sides of controversial issues are given. To carry out this responsibility the teacher should be well informed in the areas being studied. It's recognized that every teacher has the right to a point of view and to express that view, but the teacher has the responsibility to tell the students that the statement is a personal view.
\end{abstract}

Key words: Freedom, democracy, censorship, education, liberation, dialogue

\section{INTRODUCTION}

Democracy refers to the liberty of the person to carry out investigation in a scholarly manner within the structure of the academic community. It is narrowly defined as "the freedom of professionally qualified persons to inquire, discover, publish and teach the truth as they see it in the field of their competence, without any control of any authority except the control of the authority of the rational methods by which truth is established" (Worgul, 1992, p. 10). When considered this way the process includes: The unhindered freedom to explore a given subject to the extent that the rational powers of investigation are capable and the freedom to do so without influence or pressures to

\section{External Process And The Development Of Divergent View On A Given Subject.}

The obligation of the teacher is to direct to truth and the teacher who is in order to please anybody, suppress important information or saying things he \ she knows are not true or refrains from saying things that needs to be said in the interest of truth, betrays his calling and renders himself unworthy to belong in the company of teachers. If we desire to preserve any institution or concept on first necessity is to define our terms correctly and to ascertain accurately the causes of discontent. But the problems are as pressing in the school as they are in the colleges. The schoolteacher enjoys far less freedom of opinion and actions as the college professor. If democracy is to be sustained and restored, probably the emerging leadership for such accomplishment must be discovered (Kirk, 1978).

Arney and Finkel (1995) state that teachers who set their students free through education find themselves in a puzzling and problematic situation. Teaching freedom is a paradox, the 
paradox of pedagogy. They use Rousseau's Emile on setting the stage for designing education for freedom and liberation. The true individual must be so well disciplined to choose wisely and freely for himself/herself and for others. This teacher must regulate the student's freedom even as he gives it to him. "A healthy mind, a functioning and a free mind is not a mind which believes as it pleases" ( Tussman, in Arney and Finkel, 1995, p. 56). The goal of individual education is good government. Individuals must develop the authority to govern themselves and develop a responsiveness to the authority of other individuals sufficient to allow them to form a well-governed, enriching collective.

This paper will focus on democracy in the schools. It will explore the extent schools can maintain and nurture democracy to discuss ideas that are helpful to discourse. It will discuss the role of the teachers and the students in carrying out dialogue that is meaningful. The concepts of dialogue, language and the role of the teacher will be discussed and how all these compliment one another in guiding the child to grow up and take part in a meaningful democracy both in the classroom and the outside world.

\section{THE ROLE OF DEMOCRACY}

Democracy is the process that draws on the creative energy of the teachers, students and the school administration in developing a unique vision for the institution. It is the promise by an educational community that scholarly issues are openly discussed, and debated regardless of how controversial or unpopular the views expressed. Democracy in its teaching aspects is fundamental for the protection of the rights of the teacher in teaching and of the students for to learn. Schools should be committed to protecting the rights of free speech in a meaningful sense of the term without coercion or hindrance. The school administration should allow free exchange of ideas to flourish. The teachers, students and the school administrators should have respect for the rights of all individuals to speak their views freely and be heard. They must refrain from any action that would cause that right to be abridged or curtailed.

The purpose of the school is to facilitate learning and it must guard its environment from disturbing influences, which might tend to inhibit learning. Teachers must be free to select, recommend and assign those learning materials that are significant to the students and appropriate to their maturity. The selection of instruction materials and the reconsideration of these materials should include objectives critical for selection and procedures for handling complaints (Kean, 1994).

\section{DIALOGUE IN THE CLASSROOM}

Dialogue in education is necessary for one to think, speak, read, and write freely. External pressure and controls hinder the individual healthy growth as a human being. Moreover the need for dialogue and freedom as bell hooks has pointed out, "is one of the simplest way we can begin as teachers, scholars, and critical thinkers to cross boundaries, the barriers that may or may not be erected by race, gender, class, professional standing and a host of other difference... dialogue is meant to serve as a model for critical exchange between male and female... highlighting powerful moment when boundaries are crossed, difference confronted, discussion happens and solidarity emerges..."(hooks, 2000, p.129-130). Hooks is clearly stating that for meaningful dialogue to take place we have to tread on a shaky ground where no one has dared before. This means that the discourse may lead us to a controversial issue that may involve our emotions and there will be no longer any reasoning.

Greene (1995) asserts that authentic dialogue among educators is necessary so that their voices are heard with greater clarity. The voices of those who engage with the young in their concreteness and particularly the teachers should use the children stories to break through 
class polarization. She further says that, "This change has not broken through into public space, where we the teachers are very seldom inclined to speak voluntarily for ourselves... no matter what our personal inclinations, teachers especially can no longer obliterate the diverse voices, unashamed of their distinctiveness, speaking life stories and cultural stories sometimes adds with or comptemptous of the sacred writs of mainstream life... ( p. 170-71). Greene is saying that, it is those in authority who control the direction the dialogue should take and often teachers do very little to give a chance to those "others" voice their feelings. Greene (1988) is the opinion that to find such openings is to discover new possibilities-often new ways of achieving freedom in the world.

The ignorant, the uneducated, and some educated people have always threatened intellectual freedom. They do not see clearly the precious nature of such freedom and the necessity of the dialogue. They prize other values more such as national pride, conformity, and "state security" often retaining these values and letting the freedom go in the event of any conflict. A school community that aspires to foster intellectual freedom must encourage dialogue, for otherwise it will find itself with people who pay lip service to certain noble ideals and fail to develop in conduct. A democratic society whose moral premise is that each individual has a right to education that will permit him to achieve his maximum growth as a person, our duty is to work for or support whatever measures of reconstruction we deem necessary to remove the social obstacle to freedom of learning (hooks, 1984).

While writing about preserving freedom Greene (1995) quotes Madison (1988) who says that "it is through imagination, the realm of pure possibility that we freely make ourselves to be who or what we are, that we creatively, and imaginatively become who we are, while in the process of preserving freedom and possibility to be yet other than what we have become and merely are" (p.38). This means that when we imagine we accept who we are and what we want to become. Then we can think of our starting point of our next move to possibilities. Greene further asserts that it is by understanding the kind of community that offers the opportunity for democracy which also gives a chance to an emerging solidarity, sharing of central beliefs, and dialogue about others. This should be opened to newcomers and those who were thrust aside for too long. It is only in the classroom that this can happen by engaging students in dialogue freely.

In celebrating diversity and bringing together groups of diverse view into the classroom, Greene (1995) is of the opinion that the teacher should stimulate young persons to reach beyond themselves, create meanings by looking through the wider and more informed perspectives of lives. The teacher should question the child in involving him $\backslash$ her into critical thinking and attentively engage him $\backslash$ her with activities. She uses Dewey as her yardstick in his democratic education to freeing the child to make a meaning of his $\backslash$ her learning. Dewey claimed that democracy and education should go hand in hand. Democratic society and democratic education are participatory and emergent. Dewey viewed the school as a miniature democratic society in which students could learn and practice the skills and the tools necessary for democratic living (Dewey, in Reed, 1996). The young should be allowed to identify alternative possibilities and choose what they think is possible. This might help them learn on their own initiative and investigate the world.

"Freedom is an achievement in the midst of life and with other human beings. People achieve whatever freedom they can achieve through increasing consciousness and mindful transaction with what surrounds and impinges, not simply by breaking out of context and acting in response to impulse or desire..." 
(Greene, 1995, p.178). People often act when they realize that they have the power to change their situation and make a meaning of their world.

Hooks draws upon Freire's ideas to talk about the problem of race in the institution where she was teaching. Hooks believes that the classroom can be made a democratic setting where everyone feels responsible to contribute to a central goal of transformative pedagogy. "As the classroom becomes more diverse, teachers are faced with the way the politics of domination are often reproduced with the educational setting. For example, white male students continue to be the most vocal in our classes. Students of color and some women express fear that they will be judged as intellectually inadequate by those peers... some express the feeling that they are less likely to suffer any kind of assault if they simply do not assert their subjectivity" (hooks, 1994, p.136). Students often fear to voice their feeling because of the created public discourse. This identical with our ethnic problem in Kenya where minority groups voice is not heard in the public discourse. This is the norms that has been set up in past by those in power.

Greene (1973) is of the opinion that this type of students lack embeddedness in memories and histories they have been made to feel as if "they are rootless subjectivties- dandelion pods tossed by the wind. What does it mean to be a citizen of the free world? What does it mean to think forward into the future? To dream? To reach beyond? Few even dare to ponder what is to come" (p. 3).

The classroom situation which is most provocative, thoughtful, and critically conscious is the one which teachers and learners find themselves conducting a kind of collaborative search, each from her or his own lived situation. If the teacher agrees to submerge himself $\backslash$ herself into the system, if he \she consents to being defined by others' of what he is supposed to be, he gives up his freedom "to see, to understand, and to signify" for himself $\backslash$ herself. If on the other hand, he $\backslash$ she is willing to create a new perspective on what he has habitually considered real, his teaching may become the project of a person vitally open to students and the world (Greene, 1988). This is what she calls breaking through the "cotton wool".

According to Greene, the task of the teacher is to devise situations in which the young will move from the habitual and the ordinary and consciously undertake a search. Like hooks, Greene refers to Freire who insists on the arousing the child to consciousness in which he $\backslash$ she challenges the world by naming and transforming it. "Hopelessness is a form of silence of denying the world and fleeing from it ... Hope does not consist in crossing one's arms and waiting. As long as I fight, I am moved by hope, and if I fight with hope then I can wait" (Greene, 1995, p. 24). She is of the opinion that dialogue can not be carried on in a climate of hopelessness. People, who are trying to be more fully human must not only engage in critical thinking, but must be able to imagine something coming of their hopes. Their silence must be overcome by their search.

\section{THE TEACHER AND DIALOGUE}

The school can justifiably act as an instrument of intentional indoctrination only in totalitarian society. In a free society such a task is beyond its rightful jurisdiction. The school should take the role of shaping society to advocate not only for the democratization of the learning environment, but also the freedom of the teachers to make, to explore, and carry out the research that they require to make their teaching successful. There is no "taboo" subject in the classroom. Everything must be subject to common scrutiny and rational analysis, subject always to the teacher's right to decide what is the appropriate allocation of time among various topics. The teacher must admit the students to a level of equitability in the dialogue. Although the teacher is in a position of superiority with regard to the organization of the learning 
situation, once the discussion has began, both teacher and pupil are equal in the quest for truth. Usually the teacher will exercise leadership by virtue of superior maturity, knowledge, or skill, but must never use superiority of rank to alter the logical superiority of the student's argument. Finally, the teacher must not use his $\backslash$ her position of authority to force even verbal acceptance of doctrines that the students have no opportunity to study or criticize, even if the teacher is himself convinced of the truth of the doctrines.

In order to empower the teachers and maintain the educational system's wherewithal to serve democracy, the democratization of the school is imperative. As Dewey (in Reed \& Johnson, 1996) asked, "what does democracy mean save that the individual is to have a share in determining the conditions and the aims of his work, and that upon the whole through the free and mutual harmonizing of different individuals, the work of the world is better done than when planned, arranged, and directed by a few, no matter wise or how good intent that few?" (p. 196). The existing hierarchical structure with power and control at the top will need to give way to a framework that embraces a flatter, more horizontal organization.

Giroux (in Spring, 1999), states that the primary task of education is to help students understand the social construction of knowledge in the framework of power. The method of achieving this goal is critical pedagogy. Critical pedagogy prepares students to participate in the democratic struggle within the school. Critical pedagogy will let people give voice to their beliefs and engage in dialogue in the process.

Scott (1990) asserts that the dominant group produces a public transcript in close conformity of how they wish their thoughts to appear. Although the dominant never control the stage but their wish normally prevails. "It is in the interest of the subordinate to produce a more or less credible performance, speaking lines, and making gestures he knows are expected of him. The result is that the public transcript is baring a crisis systematically skewed in the direction of the libretto, the discourse, represented by the dominant. In ideological terms the public transcript will typically, by its accommodationist tone provide convincing evidence for the hegemony of dominant values, for the hegemony of dominant discourse" (p. 30). This means that the dominant group expects the dominated to say what is expected of them. There is no way they can go against this expectation. This is evident in the industrial action going around the country, where workers agitating for their rights are threatened by Kenyan Cabinet Ministers with sacking unless they return to work.

\section{DEMOCRACY AND LANGUAGE}

An educational program that fosters intellectual freedom needs to train individuals in literacy and articulateness in the language of human intercourse, both verbal and symbolic. The teachers must help students to read, listen to, and use their own language with understanding. They must be taught to distinguish between truth and propaganda, to value what they read and hear, to express themselves in speech and writing in such a way that their true intentions emerges. They must be helped to avoid the unnecessary misunderstanding and conflict that arise when their lack of articulateness prevents them from making their meaning clear. The members of a community must be trained in language to enable them to enter and continue dialogue; a community of free individuals demands the steady removal of illiteracy.

Scott (1990) says that the influence the powerful exercise on public discourse is clear about the use of language and power. These findings indicate how hierarchies of gender, race, caste and class are encoded in the domination of talk. He says, " ...n a face-to-face encounter the tone, the grammar and the dialect is in other symmetrical power relations, the dominant is typically one 
who initiates the conversation, controls its direction and terminates it" (p. 30). It is the dominant forces who control the direction of the discourse.

Greene (1998) pointed out the close connection between freedom and language. “...But I think of how much beginnings have to do with freedom, how much disruptive has to do with consciousness and awareness of possibility that has to do with teaching other human beings." She continues to say that for the teachers to truly provoke students to break through the limits of the conventional and the taken, for granted they have to experience breaks with what has been established in their lives. She is dismayed at the way education too often follows the lines of class, gender and race to permit and forbid the expression of different people's experience. "Every educational system is a political means of maintaining or modifying the appropriation of discourse, with knowledge and powers it carries with it." (p. 110). Education is the means of controlling public discourse and the schools are used effectively to play this role.

Greene believes that education is supposed to be a means of giving every person access to assort of discourse that the person preferred, that literacy is a personal achievement, a door to personal meaning. It therefore takes an effort to realize how deeply literacy is involved in relations to power and how it must be understood in context and in relation to the social world. She further asserts that people are born into culturally defined literacy that they came to acquire in the course of growing up. There are many others who are alienated or marginalized to the extent that they feel distrustful of their own voices, their own ways of making sense. These people never get an alternative to tell their stories or shape their narratives or ground new learning in which they already know. " The favored ones in contrast seldom question the language of dominance or efficiently ...although they seek out discourses for shared culture... seldom do we see a questioning of the context of technical language, pure linear or analytical discourse that presumes the objective existence of what it takes to be the "normal" world... people who lack access to the language of power, who are inarticulate even about their lived lives are unlikely to surmount the boundaries in which all customary views are confined" (Greene, 1995, p.111). The teachers have to be articulate enough and be able to exert themselves to name what they see around them.

Hooks (2000) echoes the same feelings as Greene but in a more radical manner. She says that language disrupts, refuses to be contained within the boundaries. Language she asserts intrudes into our thoughts against our will, the most private spaces of mind and body. A good example of this effect she says is Adrienne Rich's poem, " The Burning of Paper Instead of Children." This poem which speaks about domination against racism and class oppression attempts to illustrate graphically the stopping of the political presentation and the torture of a living being in a more vital issue than censorship, the burning books. There is one line in this poem that moved something in hooks, "This is the oppressor's language yet I need it to talk to you." The impression the line has created in her mind can never be erased. "Words impose themselves, take root in our memory against our will..." ( p. 167). This portrays how words can be used to create a powerful imaginary.

It is not the language hooks has a problem with but "what the oppressor does with it, how they shape it to become a territory that limits and defines, how it is made into a weapon that can shame, humiliate and colonize." She also says that one can transform the oppressor's language and turn it into a culture of resistance like the black people created an intimate speech that could say more within the boundaries of Standard English. The creation of this speech did not only resist the power of white supremacy but it also forges a space for an alternative cultural production and thinking. 


\section{THE TEACHERS AND DEMOCRACY}

The teachers have to create an environment that would allow creative thinking on the part of the students. They should see that this is possible in the classroom. It is their responsibilities to inculcate in their students the value of democracy and the worth of other individuals. They should make the school where the communities can draw together for the purpose of creating a common life and opening up new avenues for growth. Students must be encouraged to learn to judge people and ideas not by their labels but by their fruits. They must also learn that a democratic attitude towards minority groups will often involve unpopular decisions, such as giving them a voice to say their point of view.

Greene (1995) calls for teachers to include the voices of those "long silenced" to "make way for the untried and unexpected" (p. 136). While the main point of education as she sees it, "is to enable a human being to become increasingly mindful with regard to his or her situation and its untapped possibilities..."(p. 182), she also sees the school as one of the few public spaces still available for the creation of a pluralistic community. Only in such communities she believes, can we hope to achieve the kind of dialogue that Rorty calls, a dialogue in which we ground values in relationships rather than in eternal verities. Greene is interested in creating the kinds of schools in which people listen to one another. Her concern is to free students from the hostile conditions that prevent growth and flourishing. But her main focus is not on freedom from but freedom to create the kind of conditions in which "potentiality... can be actualized" (p.166).

\section{EDUCATION FOR LIBERATION}

The Brazilian educator Paulo Freire (1972) comes at the task of liberatory education with a revolutionary program mounted as "a glimmer of hope." It is based on the possibility of a social community. Freire sees no need to retreat from society instead he gets his students to disengage themselves from their immediate enmeshment in their own worlds. Education means overcoming submission. This disengagement is not a separation from society but an opening of one's eyes to the social and cultural realities that are always immediately present. To do this student and teacher must remain in the society not retreat from it.

Freire criticizes what he terms as the "banking concept" of education, an education designed for oppression. The banking concept of education begins with a thinking subject, the teacher and a knowable object, the curricular material. The knowing subject manifests his ownership of the cognizable object by articulating the truth of the object.

In general, the teacher deposits all the necessary knowledge into his students and takes all other actions on the students that are necessary to make the deposits stick. Depositing knowledge into students contributes to the objectification of students. To think that another "needs" the knowledge that one has or owns is to put the educatee in an inferior position from the outset. By trying the students fit his $\backslash$ her world one thereby asserts that it is exclusively the students not the world, that is in need of adjustment. One function of banking education, Freire reminds us is to numb students with barrage of verbalism. "It anesthetizes and inhibits creative powers" (p. 76).

The aim of banking education is control. It begins with the educator's controlling "the way the world enters into the students." This concept ends up with the students being controlled. Students meekly speak true names of known objects and hope they are pointing to the right things as the watchful teachers pass by. Freire constructed his liberartory education in 
response to his understanding of education conducted under banking concept. He calls it education as the practice of freedom by making the distinction between human and animals.

"To be human is to engage in relationship with others and with the world.

It is to experience that the world as an objective reality, independent of oneself, capable of being known...( p. 92).

To become fully human we need an education that is liberatory one that will reserve the process of submersion and enable us to become critically conscious of our situation and able to act on it in order to transform it. The goals of liberatory education is conscientization, the development of critical consciousness of one's situation and based on that consciousness, a capacity to transform the world and remake one's situation in it. Liberatory education begins in the situation of the students, everyday arena in which students live their more or less common lives. The liberatory educator does not stride from his study with a curriculum in hand but the point of departure of the dialogue between teacher and students according to Freire is the quest for curriculum.

Ira Shor (1987), one of Freire's most ardent disciples explains what it means for pedagogy to be situated. He writes that the goal asks teachers to situate learning in the students' culture, their literacy, their present cognitive and effective integrated experiential with conceptual methods and academic subjects. The argument of Freire and Shor is that instead of a curriculum coming full-blown from the Ministry of Education it must be emergent. Finding together the objects of study, how they are to be approached what is to be made of them are the common task of the teacher and the student.

Shor (1987) asserts that by changing an "object of knowledge into an object of dialogue, one comes to extraordinarily re-experience the ordinary." Objects common to ones world must be forcefully removed from their taken for granted every day context and subjected to scrutiny that their usual embeddedness in reality makes impossible. Shor says that diagnosis leads easily to reconstruction. Students who are permitted to see parts of their life as problematic will transform their life situations.

Writing is one way students can begin to undertake the act of reconstruction. But writing is not the goal of education the liberatory educator does not have any specific goal. He $\backslash$ she proscribes any attempt to design curriculum based on an informed notion of students needs. The dialogical educator must not be tempted to tell his students what they need. Such action would terminate the dialogue and differ development.

\section{SANCTIONING DEMOCRACY}

The community views the function of the educational institutions as that of handing on a cultural and social order. But the community is not ready to permit freedom to the teachers. One expects the school to select, criticize, evaluate and innovate the classroom experiences. The central aspect of the problem of democracy in the classroom lies in the element of financial support. In countries where the schools and institutions of higher learning receive grants from the government, their freedom of pursuing discourse is curtailed. The question that we need to ask is; does he who pays the piper necessarily call the tune? Does control follow support? In these countries the teachers, the schools and the universities are used as instruments of indoctrination. In these countries universities often segregate themselves from the details of everyday world, they shut themselves into what is often referred to as "ivory towers" by abdicating the leadership and giving a chance to dictatorship. 
The concept of democracy is expected to make those who hold a divergent opinion be tolerated and permitted their freedom of expression. It is a collective necessity that the rights to unpopular views and criticism protected by the state laws because the health and growth of a society depends on it. Criticisms provides improvement in society, where the society is open, the government will be criticized more than in a closed society.

When the state curtails the freedom of expression in the schools, it breeds disgruntled elements. Students and teachers will resort to grumbling and the emergence of subversive elements in the institutions that will try to find their voices in the midst of this confusion. The intention behind the grumbling is a general sense of dissatisfaction without taking responsibility for an open specific complaint. The grumbling ought to be considered as a broad thinly veiled dissent. As the case was in Kenya in the 1980's when dissenting opinion was muzzled by the government of the day leading to underground movement.

As the grumbling and discontents continues it manifest itself to a total defiance where those in authority can no longer exert their authority. Students and teachers may resort to open demonstration demanding for their rights and give meaning to their voices. In a situation like this the state can do very little to prevent mass movement that may have a far reaching repercussion. The Arab Spring that spread to North African countries in a short period is a good example despite living under dictatorship for generation. Scott (1990) gives the example of the former President of Rumania, Nicolae Ceausescu, when he wanted to demonstrate he was in charge. "The young people started to boo. They jeered the president who still appeared unaware that trouble was mounting, rattled along denouncing anti-Communist forces. The booing grew louder and was briefly heard by the television audience ... It was a moment that made Rumanians realize that their all-powerful leader was in fact vulnerable. It unleashed an afternoon of demonstration in the capital and the second night of bloodshed..." (p. 204). This will be the result of oppression and the curtailing of free speech and democratic space in the schools and institutions of higher learning.

\section{CONCLUSION}

Meaningful democracy depends largely on the success of transforming the education system to challenge domination. It is therefore imperative to educate the leadership so that they understand the meaning and the use of democracy. It is important to look at the structure of the government creating democratic space that is synonymous with freedom. The crucial instrument is implementing, evaluating, monitoring, and transformation of the learning institutions. Transforming the curriculum is the heart of democracy, but the process should flow out of the mission and objectives of the institutions. The role of the state is to establish the framework and the process through which institution can define the content of the transformation in line with national policy and objectives. The learning institutions should have the right to autonomy, which is important for the health of the institutions. It is in this type of environment those ideas can grow and nurture.

\section{References}

Finkel, D.C. \& Arney, W. R .(1995). Educating for Freedom, the Paradox of Pedagogy. New Brunswick. Rutgers University Press.

Freire, P. (1972). The Pedagogy of the Oppressed. New York. The Seasbury

Press.

Freire, P. (1985). The Politics of Education, Culture and Liberation. South Hadley, Mass. Bergin and Garvey. 
Greene, M. (1995). Releasing the Imagination: Essay on Education, the Arts and Social change. San Francisco. Jossey-Bass Publishers.

Greene, M. (1973). Teachers as Strangers. Educational Philosophy for the Modern Age. Belmont, California. Wadsworth Publishing Company.

Greene, M. (1988). The Dialectic of Freedom. New York. Teachers College, Columbia University.

hooks, bell (2000). Teaching to Transgress. Education as the Practice of Freedom. New York. Routlege.

hooks, bell (1974). In Defense of Academic Freedom. New York. Pegusus.

Kean, J. M. (1994). The Secondary English and Censorship. Brown, J. E.

(ed.). Preserving Intellectual Freedom. Fighting Censorship in our Schools. Urbana, Illinois. National Council of Teachers of English.

Reed, R. F. \& Johnson, T. W. (1996). Philosophical documents in Education. New York, Longman Publishers, USA Scott, James, C. (1990). Domination and the Arts of Resistance. Hidden Transcript. New York. Yale University Press.

Shor, I. (1987). Freire for the Classroom. A Sourcebook for Liberatory Teaching.

Portsmouth, N.H. Heinemann.

Spring, J. (1999). Wheels in the head: educational philosophy of authority, Freedom and culture from Socrates to human rights. Boston, McGraw-Hill Companies Inc.

Worgul, G. S. (1992). Issues in Academic Freedom. Pittsburgh, Duguesne University. 